\title{
Least limiting water range and physical quality of soil under groundcover management systems in citrus
}

\author{
Jonez Fidalski ${ }^{1 *}$; Cássio Antonio Tormena²; Álvaro Pires da Silva ${ }^{3}$ \\ ${ }^{1}$ IAPAR - Área de Solos, C.P. $564-87701-970$ - Paranavaí, PR - Brasil. \\ ${ }_{3}^{2} U E M$ - Depto. de Agronomia, Av. Colombo, 5790 - 87090-000 - Maringá, PR - Brasil. \\ ${ }^{3}$ USP/ESALQ - Depto. de Ciência do Solo, C.P. 09 - 13418-900 - Piracicaba, SP - Brasil. \\ *Corresponding author <fidalski@iapar.br>
}

\begin{abstract}
Machinery-based farming operations used for perennial fruit crops often damage soils, particularly if the soil is wet and prone to compaction. We hypothesized that perennial vegetation growing in the interrows of orange orchards can mitigate the soil physical degradation from machinery traffic. The objective of this study was to investigate the effects of different groundcover management systems on the soil physical quality indicators including the least limiting water range (LLWR). An experiment was started in 1993 in a Typic Paleudult to evaluate three groundcover management systems: Bahia grass (Paspalum notatum) with mowing, perennial peanut (Arachis pintoi), and natural regrowth in which weeds were controlled by herbicide. The experimental design was randomized complete block with three replications. In May 2003, 216 undisturbed soil samples were collected at $0-0.15-\mathrm{m}$ depths under and between wheel tracks in the orchard interrows. The soil bulk density, soil organic carbon content, resistance to penetration, soil water retention curve and soil resistance to penetration curve were determined in order to estimate the LLWR. The higher LLWR under wheel tracks in Bahia grass compared to perennial peanut or natural regrowth suggest that a better soil physical quality was achieved with Bahia grass.
\end{abstract}

Key words: organic carbon, soil compaction, bulk density, resistance to penetration, available water

\section{Intervalo hídrico ótimo e qualidade física do solo em sistemas de manejo nas entrelinhas de citros}

\begin{abstract}
RESUMO: Operações motomecanizadas utilizadas no manejo das entrelinhas dos pomares de frutas com frequiência causam a degradação física do solo, especialmente quando realizadas com o solo úmido e suscetível à compactação. A hipótese desse estudo é que a manutenção da vegetação permanente nas entrelinhas do pomar pode mitigar a degradação física do solo causada pelo tráfego de máquinas. O objetivo desse estudo é verificar o efeito de diferentes sistemas de manejo da cobertura permanente das entrelinhas sobre o intervalo hídrico ótimo (IHO) e a qualidade física do solo. Um experimento foi iniciado em 1993 num Argissolo Vermelho distrófico latossólico para avaliar diferentes sistemas de cobertura permanente do solo: gramínea "grama matogrosso" ou "grama batatais" (Paspalum notatum) com roçadas, amendoim forrageiro (Arachis pintoi) e vegetação espontânea manejada com herbicida. Em maio de 2003, foram coletadas 216 amostras de solo não deformadas na camada de 0-0,15 $\mathrm{m}$ de profundidade sob as posições de amostragem rodado e entrerrodado das máquinas nas entrelinhas do pomar. A densidade do solo, teor de carbono orgânico, resistência do solo à penetração, curva de retenção de água e curva de resistência do solo à penetração foram determinadas para estimar o IHO. A manutenção da cobertura do solo nas entrelinhas do pomar reduziu a compactação do solo e a utilização da gramínea proporcionou melhor qualidade física do solo no pomar de laranja.

Palavras-chave: carbono orgânico, compactação do solo, densidade do solo, resistência do solo à penetração, água disponível
\end{abstract}

\section{Introduction}

Perennial vegetation, mulching, cultivation (disking), and herbicides for weed control are used as soil management practices in interrows of orchards. However, any vegetation growing in plant rows and interrows of orchards is a strong competitor for water, nutrients, and yield (Wright et al., 2003; Belding et al., 2004). Previous studies have indicated that mowing the vegetation in the interrow and applying herbicides to the plant row are the best practices for sustainable soil management in orchards (Hogue and Neilsen, 1987; Lipecki and Berbeć, 1997).
In Brazil, orange orchards have up to 15 passes yearly by machinery to carry out cropping practices and the traffic may occur when the soils are wet and prone to compaction. Soil compaction caused by machinery traffic is a major obstacle in orchards because it reduces root growth and fruit yield (Abercrombie and Plessis, 1995). Quantifying soil physical degradation associated with compaction and their impact in the plant growth is a complex task, which may be achieved using the least limiting water range (LLWR) concept. The LLWR is a multifactor index used for describing the soil physical quality to crop production (Lapen et al., 2004; Siegel-

Sci. Agric. (Piracicaba, Braz.), v.67, n.4, p.448-453, July/August 2010 
Issem et al., 2005; Tormena et al., 2007). As a single index of soil physical quality, LLWR incorporates most of the critical measurable sources of stress that the soil imposes on crop growth. For example, in compacted soils, LLWR is reduced (Silva et al., 1994; Betz et al., 1998; Tormena et al., 1999; Araújo et al., 2004; Cavalieri et al., 2006; Leão et al., 2006).

LLWR has not yet been quantified for soils of orchards, especially under and between wheel tracks in orchards managed with different groundcover systems. We hypothesized that perennial vegetation in the interrows of an orchard can mitigate the soil compaction from machinery traffic increasing the soil physical quality. Thus, the objective of this study was to investigate the effects of different groundcover management systems on the soil physical quality indicators including the LLWR.

\section{Material and Methods}

An experiment was established under Cfa climate type (IAPAR, 2000) with a non-uniform rainfall distribution of $1,500 \mathrm{~mm}$ year $^{-1}$ in northwestern Paraná ( $22^{\circ} 51^{\prime}$ to $23^{\circ} 4^{\prime} \mathrm{S}$; $52^{\circ} 12^{\prime}$ to $52^{\circ} 27^{\prime} \mathrm{W}$, altitude of $480 \mathrm{~m}$ ), Brazil. The experimental area, previously cultivated with Brachiaria humidicola (Rendle) Schweickt, has a slope of $4 \mathrm{~cm} \mathrm{~m}^{-1}$ perpendicular to the plant rows. The soil under investigation is classified as a Typic Paleudult or Argissolo Vermelho distrófico latossólico, according to Brazilian soil classification. The particle sizes of their main horizons are in Table 1.

The experiment under non-irrigated conditions underwent three treatments using a randomized complete block design with three replications. Each field plot had three plant rows with five orange trees per row and 15 trees by experimental plot (Figure 1). The "Pêra" orange (Citrus sinsensis L. Osb.) was budded on "Rangpur" lime (Citrus limonia Osb.) to establish the orchard in the growing season of 1993; at planting, the trees were spaced $7 \times 4 \mathrm{~m}$ apart (Figure 1). The three groundcover management systems in interrows of orange plants were: i) Bahia grass (Paspalum notatum Flügge) with mechanical mowing; ii) leguminous - perennial peanut (Arachis pintoi Krap. and Greg.); and iii) natural regrowth with weeding control performed with herbicide glyphosate. Disease treatment, pest control, lime, and mineral fertilization were performed equally in all three treatments
(Auler et al., 2008). Visual evaluation at the field has shown a homogeneous soil cover under Bahia grass on the wheel and between wheel tracks while under natural regrowth and leguminous the soil cover was reduced on wheel tracks. Disease and pest control, mowing, liming and harvest have been done using a tractor with mean weight of $3,300 \mathrm{~kg}$.

In May 2003, soil sampling was carried out on two adjacent interrows representative of most of plantation. Soil samples were taken under wheel tracks at 2.5 and $4.2 \mathrm{~m}$ distance from the tree trunks, and between wheel tracks at 3.2 and $3.5 \mathrm{~m}$ (Figure 1). A total of two hundred and sixteen undisturbed soil samples were collected at depths of 0 to $0.15 \mathrm{~m}$, using cores $(5-\mathrm{cm}$ diameter by 5 -cm length).

Soil water retention curve was measured at matric potentials $(\Psi)$ of $-10,-20,-40,-60$, and $-80 \mathrm{hPa}$ on a tension table (Romano et al., 2002), and -100, $-300,-500,-700$, $-1,000,-4,000$, and $-15,000 \mathrm{hPa}$ in pressure plates (Dane and Hopmans, 2002) using eighteen samples for each $\Psi$ (three treatments, three replicates, and two sampling positions) (Silva et al., 1994). Cores have been put on suction tables or pressure plates and after equilibration at selected $\Psi$, the weight was recorded and the soil resistance to penetration (SR) was determined on each core (Tormena et al., 1999); them, they were oven dried at $105^{\circ} \mathrm{C}$ until constant weight to determine the soil water content $(\theta)$ and soil bulk density $\left(\mathrm{D}_{\mathrm{b}}\right)$. The $\mathrm{D}_{\mathrm{b}}$ 's values were determined immediately (Grossman and Reinsch, 2002). After determining $\theta$ and $D_{b}$, the soil from each core was homogenized and sieved with a $2 \mathrm{~mm}$ mesh screen for determination of the soil organic carbon content (SOC) (Walkley and Black method) and the particle size distribution (hydrometer method).

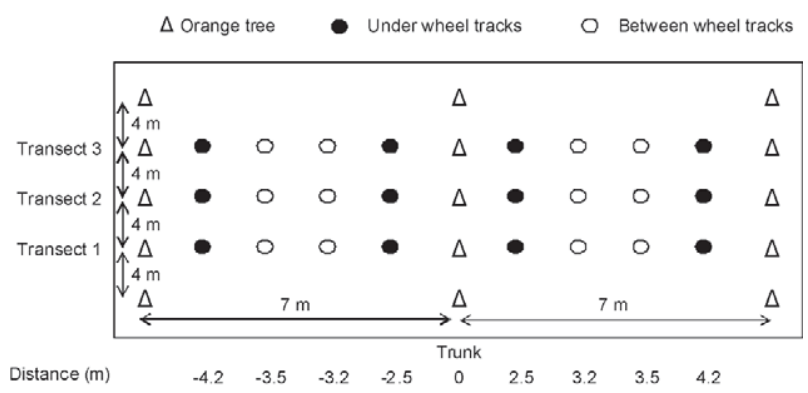

Figure 1 - Experimental plot showing three rows of orange tree and transects with 24 sampling points located under wheel tracks and between wheel tracks.

Table 1 - Particle size distributions and textural classes of soil horizons from study site.

\begin{tabular}{lccccccc}
\hline \multirow{2}{*}{ Horizon } & \multirow{2}{*}{ Depth } & \multicolumn{7}{c}{ Particle size distribution } & \multirow{2}{*}{ Textural class } \\
\cline { 3 - 7 } & $\mathrm{m}$ & Clay & Silt & Total sand & Fine sand & Coarse sand & \\
\hline & $0.00-0.06$ & 90 & 30 & 880 & 650 & 230 & Sandy \\
$\mathrm{A}$ & $0.07-0.25$ & 70 & 20 & 910 & 640 & 270 & Sandy \\
$\mathrm{AB}$ & $0.26-0.55$ & 180 & 20 & 800 & 570 & 230 & Sandy loam \\
$\mathrm{Bt}$ & $0.56-2.00$ & 210 & 20 & 770 & 560 & 210 & Sandy loam \\
\hline $\mathrm{Bw}$ & & & & & & &
\end{tabular}


The soil water retention curve was fitted to the equation proposed by van Genuchten (1980):

$\theta=\theta_{\mathrm{r}}+\left\{\left(\theta_{\mathrm{s}}-\theta_{\mathrm{r}}\right) /\left[1+(\alpha \Psi)^{\mathrm{n}}\right]^{\mathrm{m}}\right\}$

$\theta$ is the volumetric water content $\left(\mathrm{m}^{3} \mathrm{~m}^{-3}\right), \Psi$ is the matric potential $(\mathrm{hPa}), \theta_{\mathrm{r}}$ is the residual water content $\left(\mathrm{m}^{3} \mathrm{~m}^{-3}\right), \theta_{\mathrm{s}}$ is the soil water content at saturation, $\alpha\left(\mathrm{hP}^{-1}\right)$ is the reciprocal of $\Psi$, and $n$ and $m$ are constants. The parameter $m$ was assumed to be related as $[\mathrm{m}=(1-1)$ n). The $\theta_{s}$, the soil water content at saturation or total pore volume $\left(\mathrm{m}^{3} \mathrm{~m}^{-3}\right)$, was estimated as:

$\theta_{\mathrm{s}}=1-\left(\mathrm{D}_{\mathrm{b}} / \mathrm{D}_{\mathrm{p}}\right)$

$\mathrm{D}_{\mathrm{p}}$ is soil particle density $\left(\mathrm{Mg} \mathrm{m}^{-3}\right)$, which was measured by using the ethyl alcohol method (Embrapa, 1997) in each sample and the mean $\left(2.62 \mathrm{Mg} \mathrm{m}^{-3}\right)$ was used in Eq. 2.

The data for SR $(\mathrm{MPa})$ were regressed against $\mathrm{D}_{\mathrm{p}}(\mathrm{Mg}$ $\left.\mathrm{m}^{-3}\right)$ and $\theta\left(\mathrm{m}^{3} \mathrm{~m}^{-3}\right)$ using following model (Busscher, 1990):

$\mathrm{SR}=\mathrm{c} \theta^{\mathrm{d}} \mathrm{D}_{\mathrm{b}}^{\mathrm{e}}$

in which $c, d$, and $e$ are constants.

The significant effects of $D_{b}$, sampling positions, SOC and treatments (Bahia grass, perennial peanut and natural regrowth), and coefficients significant of equations 1 and 3 were performed for Fidalski and Tormena (2007), according to Tormena and Silva (2002).

The LLWR was determined for each soil sample (Silva et al., 1994). The soil water limits to $\theta$ were estimates, from field capacity at $\Psi=-80 \mathrm{hPa}\left(\theta_{\mathrm{fc}}\right)$ to wilting point at $\Psi=-15,000 \mathrm{hPa}\left(\theta_{\mathrm{wp}}\right)$; both were calculated using their water retention curve equation (Eq. 1). An estimate of $\theta\left(\theta_{\mathrm{sr}}\right)$ establishing SR critical to root growth equal to 2.2 $\mathrm{MPa}$ (Abercrombie and Plessis, 1995) was obtained from the Eq. 3; the estimates of $\theta$ for air-filled porosity $\left(\theta_{\text {afp }}\right)$ of $0.10 \mathrm{~m}^{3} \mathrm{~m}^{-3}$ (Grable and Siemer, 1968) were calculated:

$\theta_{\text {afp }}=\theta_{\mathrm{s}}-0.1$

The Available Water Capacity (AWC) was calculated from $\theta$ estimates at $\Psi=-80 \mathrm{hPa}$ or field capacity $\left(\theta_{\mathrm{fc}}\right)$ to wilting point at $\Psi=-15,000 \mathrm{hPa}\left(\theta_{\mathrm{wp}}\right)$ :

$\mathrm{AWC}=\theta_{\mathrm{fc}}-\theta_{\mathrm{wp}}$

The LLWR values were grouping by sampling positions according to $\mathrm{D}_{\mathrm{b}}$ : i) between wheel tracks; ii) under and between wheel tracks; iii) under wheel tracks (Figures 2 and 3).

A completely randomized design in scheme split-plot (Gomez and Gomez, 1984) was used to evaluate the experimental data from different treatments and sampling positions (means $n=12$ ). To determine significant differences among the mean values, ANOVA and Tukey tests at $10 \%$ were used for comparing data from treatments and sampling positions (SAS Institute, 2001).

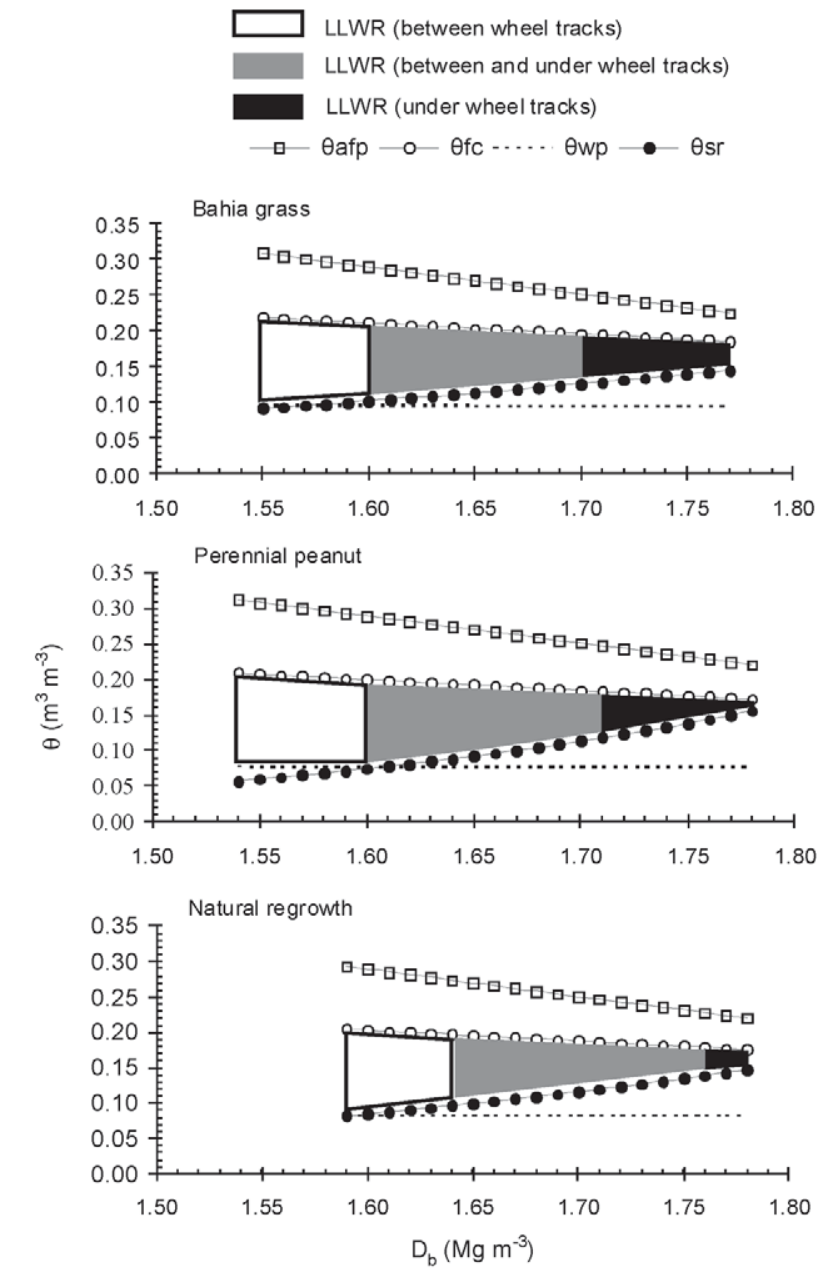

Figure 2 - Relationship between soil bulk density $\left(D_{b}\right)$ and volumetric water content $(\theta)$ with three treatments, under and between wheel tracks, at critical levels of field capacity $\left(\theta_{\mathrm{fc}}\right)$ and wilting point $\left(\theta_{\mathrm{wp}}\right)$, at airfilled porosity $\left(\theta_{\text {ff }}\right)$ and soil resistance to penetration $\left(\theta_{\mathrm{ss}}\right)$. The areas (white, grey and black) correspond to the least limiting water range (LLWR).

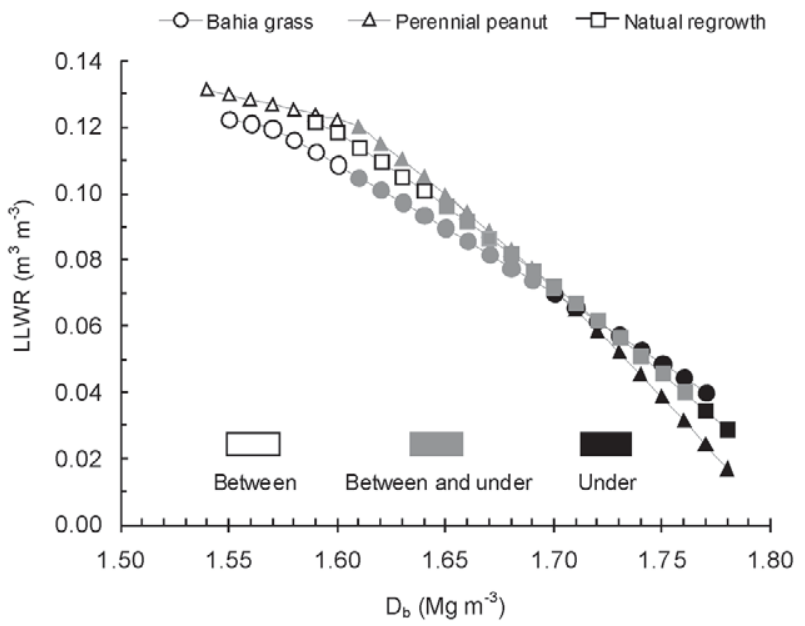

Figure 3 - Relations between soil bulk density $\left(D_{b}\right)$ and least limiting water range (LLWR) of soil under three treatments and sampling positions. 


\section{Results and Discussion}

The $\mathrm{D}_{b}, \theta$, SR and SOC data were dispersed to sampling positions and three treatments (Table 2). There was no influence of sampling position on the soil water retention curve (Table 3), indicating that compaction under wheel track has affected mainly the large pores with no capillary action. However, there was an effect of treatments on $\theta$, which was dependent of $\mathrm{D}_{\mathrm{b}}$ and SOC. The treatments have promoted modification in soil pore size distribution in addition to those effects from SOC and $\mathrm{D}_{\mathrm{b}}$, possibly associated with drying-wetting cycles, amount and type of replenished plant roots from groundcover systems. The increase in $\mathrm{D}_{\mathrm{b}}$ reduced $n$ pa- rameter and established a decrease in $\theta$ (Tormena and Silva, 2002). Otherwise, the $\theta_{r}$ was positively influenced by SOC (Rawls et al., 2003). Interactions among $\mathrm{D}_{b}$, SOC and the soil water retention curve parameters have established similar differences in the AWC between treatments (Figure 2), which were observed in another study (Tormena et al., 1999).

Effects of groundcover management systems and SOC were found in the soil resistance curve parameters, which were not influenced by sampling position (Table 3). The positive effect of SOC reduced the $c$ coefficient value, and as a result a lower SR, probably due to the lower $\mathrm{D}_{\mathrm{b}}$ of the soil aggregates. The lower SOC in the soil under natural regrowth produces the higher value

Table 2 - Soil physical properties and soil organic carbon content at $0-0.15 \mathrm{~m}$ depth under three treatments and two sampling positions $(\mathrm{n}=36)$.

\begin{tabular}{|c|c|c|c|c|c|c|c|c|}
\hline \multirow{2}{*}{ Treatment } & \multicolumn{4}{|c|}{ Between wheel tracks } & \multicolumn{4}{|c|}{ Under wheel tracks } \\
\hline & Min. & Mean & Max. & $\mathrm{CV}$ & Min. & Mean & Max. & $\mathrm{CV}$ \\
\hline & & & & $\%$ & & & & $\%$ \\
\hline & \multicolumn{8}{|c|}{ Soil bulk density $\left(\mathrm{Mg} \mathrm{m}^{-3}\right)$} \\
\hline Bahia grass & 1.55 & 1.63 & 1.70 & 2 & 1.60 & 1.68 & 1.77 & 2 \\
\hline Perennial peanut & 1.54 & 1.64 & 1.71 & 3 & 1.60 & 1.70 & 1.78 & 3 \\
\hline \multirow[t]{2}{*}{ Natural regrowth } & 1.59 & 1.67 & 1.76 & 3 & 1.64 & 1.72 & 1.78 & 2 \\
\hline & \multicolumn{8}{|c|}{ Soil water content $\left(\mathrm{m}^{3} \mathrm{~m}^{-3}\right)$} \\
\hline Bahia grass & 0.06 & 0.17 & 0.38 & 63 & 0.05 & 0.18 & 0.36 & 58 \\
\hline Perennial peanut & 0.05 & 0.16 & 0.35 & 67 & 0.05 & 0.17 & 0.36 & 68 \\
\hline \multirow[t]{2}{*}{ Natural regrowth } & 0.05 & 0.16 & 0.38 & 71 & 0.05 & 0.16 & 0.35 & 68 \\
\hline & \multicolumn{8}{|c|}{ Soil resistance to penetration $(\mathrm{MPa})$} \\
\hline Bahia grass & 0.35 & 1.81 & 6.32 & 83 & 0.28 & 2.02 & 6.15 & 75 \\
\hline Perennial peanut & 0.27 & 1.69 & 6.13 & 87 & 0.28 & 2.50 & 10.36 & 96 \\
\hline \multirow[t]{2}{*}{ Natural regrowth } & 0.30 & 1.96 & 4.63 & 74 & 0.23 & 2.96 & 10.75 & 98 \\
\hline & \multicolumn{8}{|c|}{ Soil organic carbon $\left(\mathrm{g} \mathrm{kg}^{-1}\right)$} \\
\hline Bahia grass & 2.77 & 5.19 & 8.14 & 25 & 3.59 & 5.37 & 7.98 & 21 \\
\hline Perennial peanut & 3.16 & 5.35 & 7.98 & 26 & 3.16 & 5.02 & 8.55 & 24 \\
\hline Natural regrowth & 2.37 & 4.76 & 6.51 & 25 & 2.77 & 4.63 & 7.33 & 20 \\
\hline
\end{tabular}

$\mathrm{CV}=$ coefficient of variation.

Table 3 - Soil water retention curve and soil resistance to penetration curve for three treatments (Eq. 1 and 2).

\begin{tabular}{|c|c|}
\hline Treatment & Equations \\
\hline & Soil water retention curve $\left(\mathrm{R}^{2}=0.94 ; p<0.0001 ; \mathrm{n}=216\right)$ \\
\hline Bahia grass & $\theta=(0.115+0.006 \mathrm{SOC})+\left\{\left[\theta_{s}-(0.115+0.006 \mathrm{SOC})\right] /\left[1+(0.019 \Psi)^{\left.\left(10.48-4.74 \mathrm{D}_{\mathrm{b}}\right)\right]\left\{1-1 / 1\left(10.48-4.74 \mathrm{D}_{\mathrm{b}}\right\}\right.}\right\}\right.$ \\
\hline Perennial peanut & $\theta=(0.097+0.006 \mathrm{SOC})+\left\{\left[\theta_{\mathrm{s}}-(0.097+0.006 \mathrm{SOC})\right] /\left[1+(0.019 \Psi)^{\left.\left(10.48-4.74 \mathrm{D}_{\mathrm{b}}\right)\right]\left\{1-1 /\left(10.48-4.74 \mathrm{D}_{\mathrm{b}}\right)\right\}}\right\}\right.$ \\
\hline \multirow[t]{3}{*}{ Natural regrowth } & $\theta=(0.106+0.006 \mathrm{SOC})+\left\{\left[\theta_{\mathrm{s}}-(0.106+0.006 \mathrm{SOC})\right] /\left[1+(0.019 \Psi)^{\left.\left(10.48-4.74 \mathrm{D}_{\mathrm{b}}\right)\right]\left\{1-1 /\left(10.48-4.74 \mathrm{D}_{\mathrm{b}}\right)\right\}}\right\}\right.$ \\
\hline & $\theta=(0.106+0.006 \mathrm{SOC})+\left\{\left[\theta_{\mathrm{s}}-(0.106+0.006 \mathrm{SOC})\right] /\left[1+(0.019 \Psi)^{\left.\left(10.48-4.74 \mathrm{D}_{\mathrm{b}}\right)\right\}\left\{1-1 /\left(10.48-4.74 \mathrm{D}_{\mathrm{b}}\right)\right\}}\right\}\right.$ \\
\hline & Soil resistance to penetration curve $\left(\mathrm{R}^{2}=0.87 ; p<0.0001 ; \mathrm{n}=216\right)$ \\
\hline Bahia grass & $\mathrm{SR}=(0.020+1.065 \mathrm{SOC})^{1.12} \mathrm{D}_{\mathrm{b}}{ }^{3.90}$ \\
\hline Perennial peanut & $\mathrm{SR}=(0.002+1.065 \mathrm{SOC})^{1.12} \mathrm{D}_{\mathrm{b}}^{7.71}$ \\
\hline Natural regrowth & $\mathrm{SR}=(0.007+1.065 \mathrm{SOC})^{1.12} \mathrm{D}_{\mathrm{b}}^{5.81}$ \\
\hline
\end{tabular}

Sci. Agric. (Piracicaba, Braz.), v.67, n.4, p.448-453, July/August 2010 
of $c$ coefficient, indicating the highest SR in this treatment (Table 2). The higher value of $e$ coefficient at soil under perennial peanut indicates higher increases in SR with $\mathrm{D}_{\mathrm{b}}$; in comparison with natural regrowth. This effect is compensated by the higher SOC, which reduces the SR. Despite this SOC was not different between Bahia grass and perennial peanut (Fidalski et al., 2007), the higher value of $e$ coefficient could be related to soil structural effects at microaggregates level due to physicochemical characteristics of SOC under these treatments.

The LLWR limits, i.e., $\theta_{\mathrm{fc}}, \theta_{\mathrm{wp}}, \theta_{\mathrm{sr}}$ and $\theta_{\text {afp }}$ were influenced by groundcover systems (Figure 2). The $\theta_{\mathrm{fc}}$ decreased with increasing $\mathrm{D}_{\mathrm{b}}$ whereas $\theta_{\mathrm{wp}}$ was constant in all treatments. Higher AWC under perennial peanut was due to the low $\theta_{\mathrm{wp}}$, because $\theta_{\mathrm{fc}}$ values were similar in all treatments. The Bahia grass system induced the lowest AWC in the soil, followed by the natural regrowth. Considering AWC, perennial peanut would be the best groundcover management system for orange trees in terms of soil physical quality. For all treatments $\theta_{\mathrm{fc}}$ was the upper limit of the LLWR. Similar results were reported for sandy and sandy-loam soils (Silva et al., 1994; Leão et al., 2006). Lack of aeration was not a problem in this soil since $\theta_{\text {afp }}>\theta_{\mathrm{fc}}$ within $\mathrm{D}_{\mathrm{b}}$ range. Regardless treatment and sampling position, LLWR = AWC for 1.54 $<\mathrm{D}_{\mathrm{b}}<1.62 \mathrm{Mg} \mathrm{m}^{-3}$. For $\mathrm{D}_{\mathrm{b}}>1.63 \mathrm{Mg} \mathrm{m}^{-3}, \theta_{\text {sr }}$ replaced $\theta_{\text {wp }}$ as the LLWR lower limit (Figure 2). Bahia grass induced a higher LLWR than perennial peanut or natural regrowth (Figure 3). The $\mathrm{D}_{\mathrm{b}}=1.70 \mathrm{Mg} \mathrm{m}^{-3}$ indicates a $D_{b}$ threshold level beyond which the treatment modifies the LLWR performance; thereafter, Bahia grass performed better than other treatments. The SR negative effect on LLWR was higher for perennial peanut and natural regrowth than Bahia grass. The lower $\theta_{\mathrm{sr}}$ in Bahia grass indicates the positive effects of this treatment on the soil physical quality, probably due to the large number of fine roots than perennial peanut (Doss et al., 1960; Fischer and Cruz, 1993).

There was an interaction between treatments and sampling positions to LLWR (Table 4). The LLWR did not vary among the treatment between tracks and it was higher than the one under wheel track treatment. The LLWR mean values indicated differences in the soil physical quality under wheel tracks to Bahia grass and natural regrowth. However, in perennial peanut, the LLWR did not vary in relation to the Bahia grass and to the natural regrowth under the wheel track. The use of perennial peanut increased the risk of water deficits, as indicated by the lower LLWR. In this experiment there was a reduction in the photosynthesis rate and stomatal conductance of orange trees under perennial peanut (Fidalski et al., 2006; 2008). The higher drying effect in the perennial peanut may imply on high frequency of SR values above $2.2 \mathrm{MPa}$ which may induce soil strength stress on the root system.

Growing grass in the interrows of groves was recommended by other authors (Hogue and Neilsen, 1987; Lipecki and Berbeć, 1997). Soil under Bahia grass man-
Table 4 - Least limiting water range under three treatments and two sampling positions.

\begin{tabular}{lcc}
\hline \multirow{2}{*}{ Treatment } & \multicolumn{2}{c}{ Sampling position } \\
\cline { 2 - 3 } & $\begin{array}{c}\text { Between wheel } \\
\text { tracks }\end{array}$ & $\begin{array}{c}\text { Under wheel } \\
\text { tracks }\end{array}$ \\
\hline Bahia grass & $0.095 \mathrm{Aa}$ & $0.079 \mathrm{Ab}$ \\
Perennial peanut & $0.103 \mathrm{Aa}$ & $0.069 \mathrm{ABb}$ \\
Natural regrowth & $0.086 \mathrm{Aa}$ & $0.061 \mathrm{Bb}$ \\
\hline
\end{tabular}

Capital letters differs treatments into sampling positions and small letters differs sampling positions into treatments (Tukey, $p<0.10)$

agement yield the best physical quality, enhances water relationships, and provided a better physiological condition for sustainable fruit yield (Fidalski et al., 2006). These achievements are different from previous studies, which suggested that trees compete for water under the groundcover vegetation (Glenn and Welker, 1989; Johns, 1994; Wright et al., 2003). This study suggests that Bahia grass may help to minimize the risks of soil compaction by agricultural machinery and thereby may enhance the physical quality of orange orchard soil.

\section{References}

Abercrombie, R.A.; Plessis, S.F.D. 1995. The effect of alleviating soil compaction on yield and fruit size in an established Navel orange orchard. Journal of the Southern African Society for Horticulture Sciences 5: 85-89.

Araújo, M.A.; Tormena, C.A.; Silva, A.P. 2004. Physical properties of a dystrophic Red Latosol (Oxisol) under crop cultivation and native forest. Revista Brasileira de Ciência do Solo 28: 337-345. (in Portuguese, with abstract in English).

Auler, P.A.M.; Fidalski, J.; Pavan, M.A.; Neves, C.S.V.J. 2008. Fruit yields of 'Pêra' orange under different soil tillage and interrow management systems. Revista Brasileira de Ciência do Solo 32: 363-374. (in Portuguese, with abstract in English).

Belding, R.D.; Majek, B.A.; Lokaj, G.R.W.; Hammerstedt, J.; Ayeni, A.O. 2004. Orchard floor management influence on summer annual weeds and young peach tree performance. Weed Technology 18: 215-222.

Betz, C.L.; Allmaras, R.R.; Copeland, S.M.; Randall, G.W. 1998. Least limiting water range: traffic and long-term tillage influences in a Webster soil. Soil Science Society of America Journal 62: 1384-1393.

Busscher, W.J. 1990. Adjustment of flat-tipped penetrometer resistance data to a common water content. Transactions of the ASAE 33: 519-524.

Cavalieri, K.M.V.; Tormena, C.A.; Vidigal Filho, P.S.; Gonçalves, A.C.A.; Costa, A.C.S. 2006. Influence of mechanical load levels on physical properties of a eutric cambisol. Revista Brasileira de Ciência do Solo 30: 137-147. (in Portuguese, with abstract in English).

Dane, J.H.; Hopmans, J.W. 2002. Pressure Plate Extractor. In: Dane, J.H.; Topp, C., eds. Methods of Soil Analysis, Physical Methods. SSSA, Madison, WI, USA. p. 688-690.

Doss, B.D.; Ashley, A.; Bennett, O.L. 1960. Effect of soil moisture regime on root distribution of warm season forage species. Agronomy Journal 52: 569-572.

Empresa Brasileira de Pesquisa Agropecuária [EMBRAPA]. 1997. Methods of soil analyses procedures. 212p. Centro Nacional de Pesquisa de Solos, Rio de Janeiro. (Embrapa-CNPS Documentos, 1). (in Portuguese). 
Fidalski, J.; Tormena, C.A. 2007. Pedotransfer functions for the soil water retention and soil resistance to penetration under groundcover management systems in citrus. Ciência Rural 37: 1316-1322. (in Portuguese, with abstract in English).

Fidalski, J.; Marur, C.J.; Auler, P.A.M.; Tormena, C.A. 2006. Orange yield in orchard floor vegetation management. Pesquisa Agropecuária Brasileira 41: 927-935. (in Portuguese, with abstract in English).

Fidalski, J.; Tormena, C.A.; Silva, A.P. 2007. Soil physical quality in an orange orchard in northwestern Paraná as affected by groundcover management. Revista Brasileira de Ciência do Solo 31: 423-433. (in Portuguese, with abstract in English).

Fidalski, J.; Marur, C.J.; Tormena, C.A. 2008. Physiological responses of orange trees to permanent groundcover vegetation types. Revista Brasileira de Ciência do Solo 32: 1307-1317. (in Portuguese, with abstract in English).

Fischer, M.J.; Cruz, P. 1993. Some ecophysiological aspects of Arachis pintoi. p. 53-70. In: Kerridge, P.C.; Hardy, B., eds. Biology and agronomy of forage Arachis. CIAT, Cali, Colombia. (CIAT Publication, 240). (in Spanish, with abstract in English).

Glenn, D.M.; Welker, W.V. 1989. Orchard soil management systems influence rainfall infiltration. Journal of the American Society of Horticultural Science 114: 10-14.

Gomez, K.A.; Gomez, A.A. 1984. Two-factor experiments. p. 84129. In: Gomez, K.A.; Gomez, A.A., eds. Statistical procedures for agricultural research. 2ed. John Wiley, New York, NY, USA.

Grable, A.R.; Siemer, E.G. 1968. Effects of bulk density, aggregate size, and soil water suction on oxygen diffusion, redox potentials, and elongation of corn roots. Soil Science Society of America Journal Proceedings 32: 180-186.

Grossman, R.B.; Reinsch, T.G. 2002. Bulk density and linear extensibility. p. 201-228. In: Dane, J.H.; Topp, C., eds. Methods of soil analysis: physical methods. SSSA, Madison, WI, USA.

Hogue, E.J.; Neilsen, G.H. 1987. Orchard floor vegetation management. Horticulture Review 9: 377-430.

Instituto Agronômico Do Paraná [IAPAR]. 2000. Climate Atlas of the State of Paraná, Brazil; Versão 1.0. IAPAR, Londrina, PR, Brazil. CD-ROM. (in Portuguese).

Johns, G.G. 1994. Effect of Arachis pintoi groundcover on performance of bananas in northern New South Wales. Australian Journal of Experimental Agriculture 34: 1197-1204.

Lapen, D.R.; Topp, G.C.; Gregorich, E.G.; Curnoe, W.E. 2004. Least limiting water range indicators of soil quality and corn production, eastern Ontario, Canada. Soil Tillage and Research 78: $151-170$.
Leão, T.P.; Silva, A.P.; Macedo, M.C.M.; Imhoff, S.; Euclides, V.P.B. 2006. Least limiting water range: a potential indicator of changes in near-surface soil physical quality after the conversion of Brazilian Savanna into pasture. Soil Tillage and Research 88: 279-285.

Lipecki, J.; Berbeć, S. 1997. Soil management in perennial crops: orchards and hop gardens. Soil Tillage and Research 43: 169184.

Rawls, W.J.; Pachepsky, Y.A.; Ritchie, J.C.; Sobecki, T.M.; Bloodworth, H. 2003. Effect of soil organic carbon on soil water retention. Geoderma 116: 61-76.

Romano, N.; Hopmans, J.W.; Dane, J.H. 2002. Suction table. p.692698. In: Dane, J.H.; Topp, C. eds. Methods of soil analysis: physical methods. SSSA, Madison, WI, USA.

SAS Institute. 2001. SAS/STAT User's Guide; Version 8.2. Statistical Analysis System Institute, Cary, NC, USA.

Siegel-Issem, C.M.; Burger, J.A.; Powers, R.F.; Ponder, F.; Patterson, S.C. 2005. Seedling root growth as a function of soil density and water content. Soil Science Society of America Journal 69: 215226.

Silva, A.P.; Kay, B.D.; Perfect, E. 1994. Characterization of the least limiting water range of soils. Soil Science Society of America Journal 58: 1775-1781.

Tormena, C.A.; Silva, A.P. 2002. Incorporation of the bulk density to two models adjusted to the soil water retention curve. Revista Brasileira de Ciência do Solo 26: 305-314. (in Portuguese, with abstract in English).

Tormena, C.A.; Araújo, M.A.; Fidalski, J.; Costa, J.M. 2007. Influence of mechanical load levels on physical properties of a eutric cambisol. Revista Brasileira de Ciência do Solo 31: 211219. (in Portuguese, with abstract in English).

Tormena, C.A.; Silva, A.P.; Libardi, P.L. 1999. Soil physical quality of a Brazilian Oxisol under two tillage systems using the least limiting water range approach. Soil Tillage and Research 52: 223-232.

van Genuchten, M.T. 1980. A closed-form equation for predicting the hydraulic conductivity of unsaturated soils. Soil Science Society of America Journal 44: 892-898.

Wright, G.C.; McCloskey, W.B.; Taylor, K.C. 2003. Managing orchard floor vegetation in flood-irrigated citrus groves. HortTechnology 13: 668-677.

Received August 19, 2008

Accepted April 06, 2010 